\title{
EFL Teachers' Perceptions of Information Gap Activities in Teaching Speaking and Their Reflections on the Use of These Activities in Their Classrooms
}

\begin{abstract}
Nguyen Thi Mai Duyen
Abstract: In teaching speaking, information gap activities are viewed as a useful tool which provides many advantages in teaching speaking language owning to the benefits it offers. Information gap activities give learners real motivation to communicate as they have opportunities to practice in actual situations. They give learners the chance to exchange information through communication. This research aims to investigate EFL teachers' perceptions of information gap activities (IGAs) in teaching speaking English and to explore teachers' reflections on the use of these activities in their classroom. The research adopted both quantitative and qualitative approaches. Data was collected using a questionnaire with 43 secondary school EFL teachers the Mekong Delta and in-depth interviews. We found that teachers interviewed had good perceptions of the use of information gap activities. Their knowledge of the roles, usefulness and characteristics of information gap activities as well as of how to use these activities effectively through their reflection on how they use these activities in their classrooms.
\end{abstract}

Key words: information gap activities (IGAs), teaching speaking, perceptions, reflections

\section{INTRODUCTION}

In the current trend of globalization, speaking English plays an important role in our life. It is an oral means that people use to communicate with others around the world. According to By gate $(987,22)$ good processing spoken words should be "good communication" which means good at saying what they want to say in a way which the listeners find understandable (Holubec, 2012).Harmer (1990) stated the aim of teaching speaking is to train students for communication(Defrioka, 2017), in other words, Richard (2001), main goal of teaching speaking is to help students to use English for communication, express the ideas or share information. in real - life situation(International-Journal-of-Research-in-English-Education-2538-3027, n.d.).Therefore, teachers who teach speaking in the English classroom should ask students to complete their task by interacting with their peers or cooperating through pair-work or group-work activities Krupa-kwiatkowski, (1998) said interaction entails participation, personal involvement and expression of initiative. in some ways that are thought to stimulate cognitive process conductive to language(Tsou, 2005). Larasati et al, (2018 cited in Rafsanjani et al., 2020)states that the more students practice sharing their ideas, the better their speaking abilities become. The students should practice more in order to overcome difficulties in speaking English. Yet, in Viet Nam, EFL students have been observed to speak a little or passively in the classroom. They usually feel it difficult to interact and give responses in English conversations. That can be caused by many things including the widely accepted fact that most of them are taught how to speak by memorizing and repeating or having little time to practice speaking with friends at school. In addition, some teachers also face challenges in teaching speaking in English because of their limited knowledge of how to encourage students and of classroom teaching practices, because of students' lack of confidence and low participation and because many students find it boring to practice speaking drills. Students certainly need an authentic atmosphere to reflect and to get more opportunities to swap their ideas, thought and opinions(Phan, 2017).

As basic requirement for teaching students to speak in English is to use speaking activities that are relevant to the context of students, and which create opportunities for students to be motivated, engaged, and involved in 
activities where they really have a chance to think and use the language to get information they want. Information gap activities (IGAs) which provide a structured approach for exchanging information, have long been considered an appropriate tool for teaching speaking. Richard (2006) believed that the information gap is a method to help students to practice in real contexts without repeating and memorizing (Rafsanjani et al., 2020) The main goal of information gap activities is to practice speaking fluently without learning new information. There are many benefits of these activities, which gives students a chance to practice skills and language they have already learnt. Additionally, in teaching learning process, teachers' thought is influenced by teachers' background knowledge and life experiences, their goals, teaching procedures, materials, classroom interactions and their roles in class and their students as well. Therefore, it is necessary to exam the perception of EFL secondary teachers of information gap activities and their reflection on using these activities in their classroom. This study is therefore aimed to answer the following research questions

1. What are EFL teachers' perceptions of information gap activities in teaching speaking?

2. What are EFL teachers' reflections on the use of information gap activities in their speaking classes?

\section{LITERATURE REVIEW}

\section{A. Teaching speaking}

People can identify and express what they think and feel by using language in spoken or written form. Of these two forms, speaking is a synchronous form of oral communication which takes place in real - time with instant engagement such as a conversation with a friend and is different from other delayed forms such as writing. It is one of the most important skills people use to communicate with others, and to exchange ideas and gets the information that happen in the world (Florez and Cunningham, 1999:20 cited in Natsir, 2016). It is also related to prosodic features such as intonation, pitch, word stress and so on. According to Mazouzi (2013), learners' activities should be developed in relationship of accuracy and fluency achievements (Abugohar et al., 2019).

Related to the effective activities an EFL teacher should use in teaching speaking, Nunan (2003) stated five principles for teaching speaking(Bailey, 2003). Firstly, teachers should distinguish the differences between second language and foreign language. Secondly, teachers ought to provide students activities to practice with fluency and accuracy. Thirdly, teachers should create an environment for students to work in groups or pairs and limit the teacher's talk. Fourthly, teachers should use speaking tasks involving negotiation of meaning. Fifthly, teachers should create classroom activities provide guidance and practice in both transactional and interactional speaking

\section{B. Information gap activities}

\section{Characteristic of information gap activities}

Information gap means "a gap" between the two (persons) in the data they have (Harmer,1991; Abdul, 2013, and sharing information helps to unite that gap so that both speakers have the same information (Defrioka, 2017). IGAs can also be used in group activities, where one group has half of the information that is required to complete a task and another group has the other half. Then the two groups need to exchange information to finish the task. In IGAs, students should use target language to share missing information with their partners (Afrial, 2015; Arung, 2015). In other words, information gap activities enable students to find and share it to solve problems, and make decision.

Almziad,(2020) pointed out that Information gap activity is characterized as follows "in each activity the student is given a task; The information they need for the task is split into two parts (student A and student B), no student has enough information to be able to do it alone; The students have to ask each other for the information they need and come to a decision together; The activities are not exercises, but contexts in which the students can use language to find out about things they genuinely need to know and to share ideas". 
McDonough and Show (2012) as cited in Almziad, (2020) pointed out that information gap activity is characterized as follows:

- In each activity the student is given a task;

- The information they need for the task is split into two parts (student A and student B), no student has enough information to be able to do it alone;

- The students have to ask each other for the information they need and come to a decision together;

- The activities are not exercises, but contexts in which the students can use language to find out about things they genuinely need to know and to share ideas.

\section{Types of information gap activities}

In general, information gap activities consist of two types, One-way and Two - way. According to McKay and Tom, (1999) one-way occurs when one person holds information which other group members do not have. In contrast with One-way, Ellis, (1999) states that both learners have information to share to complete the activity. The Two -way seems to be better activity rather than One-way because Two-way activity is more communicative and performing more action verbal interaction is required to complete the tasks (Arung, 2015).

\section{The usefulness of Information gap activities}

According to American English Associate (2012), there are five major well defined benefits for the teachers to apply information gap activities in speaking classroom. Firstly, IGAs promote a student-centered classroom. The two students will have chances to ask each other questions to which they do not know the answer in order to achieve the goal of their activities. Secondly, IGAs help increase intrinsic motivation by giving students a reason to talk and keeps them thinking. Thirdly, IGAs promote peer-to-peer collaboration. Students must often collaborate with their classmate(s) to successfully achieve the aims of the activity. Fourthly, IGAs are conducive to using authentic situational materials because they allow teachers to customize information gap activities to meet the real spoken English needs. Lastly, IGAs help to increase students' taking time through active collaboration with classmates to achieve the goals of activity while the teacher facilitates the preparation, and setting up activities, scaffolding and provides scaffolding and support.

\section{The guidelines for using information gap activities}

$\mathrm{Li}$, (2015) provide the following guidelines for using IGAs to teach speaking to students:

- Prepare the IGAs carefully to maximize the opportunity for students to speak: The students should be expected to try and do with success with careful preparation. Information gap tasks may be devised to control tightly or freely practice exponents which need first to be presented or revised;

- Pre-teach key vocabulary: The teacher should ensure that students are pre-taught any vocabulary that might be unfamiliar;

- Provide clear instructions: Instructions should be crystal clear to be sure that all students know what to do. Teachers may make a model of what the students should say during activity;

- Mix abilities of students in groups: Teacher should group students with different aptitudes for learning language, different degrees of motivation and very different levels of ability and encourage better students to help their less able classmate.

In the same vein, Zhang, (2004) suggested some strategies applicable for teaching speaking. Firstly, the teacher should make a plan and do preparing for the group work activities ahead of the speaking lesson (Sato, 2003). 


\section{DOI: $\underline{10.51386 / 25815946 / i j s m s-v 4 i 4 p 132}$}

Secondly, the engagement of the teacher within the cluster work is vital (Ellis, 2003). Thirdly, the teacher ought to allot roles to every member within group reasonably (Sato, 2003). Mixed teams as well as totally different members will work better than "homogeneous groups" (Defrioka, 2017)

\section{METHODOLOGY}

This study employed mixed method descriptive design combining both quantitative and qualitative approaches (Litchman, 2013). A questionnaire was used as a quantitative instruments and an interview served as a qualitative instrument to answer the two research questions. The questionnaire was composed two part, the first to measure teachers' perceptions of IGA in teaching speaking and the second to find out how teachers thought and used these activities in their speaking classrooms. The interview was carried out to gain greater insights into teachers' thoughts that may not have been captured by the questionnaire data.

For the first stage, forty-three teachers from 13 secondary schools in the Mekong Delta were invited to take part in the survey questionnaire by giving their answers to each five - cluster item in the questionnaire without any time constraint. The questionnaire was divided into sections with a numbers off statements relating to a particular aspect. As a scoring, I used a Likert scale between 1 and 5 and for each section off results. Each number on the Liker scale presented manuscripts that I have edited tend to use 1-strongly disagree, 2-disagree, 3-neutral,4-agree, 5strongly agree to measure their perception of IGAs in teaching speaking and use 1-never,2-sometimes,3-often,4usually, 5-always to check their reflection on the of use these activities in the speaking classroom.. Quantitative data gathered from the survey were then analyzed using the SPSS statistic package (v20). For the second phase, qualitative data, four teachers who were willing to take part in one-to one interview were contacted. All interviews were recorded and transcribed verbatim.

There have been numerous studies involving IGAs in teaching speaking. The use of information gap activities in teaching speaking by researcher (Defrioka, 2017)whose study aims to check to what extend the applying IGAs could improve the students' ability and how students respond about the use of these activities. Data was conducted through observation checklist, test, and interview. The result indicated that the implementation of IGAs can better improve the students' abilities. Besides, the classroom action research process itself helped students and teachers reflect on their success and failures in teaching learning process. Similarly, the effectiveness of IGAs can be clearly seen in the case of the study conducted by both researchers (Ismaili \& Bajrami, 2016). They examined the methodology strategies that IGAs techniques provide and its effectiveness to increase speaking competence. The researcher revealed that the use of IGAs students improved their speaking skill after the implementation of these activities, students felt more confident to speak in English. They were enthusiastic in doing the activities and their motivation of learning and using the language improve. Likely, the effectiveness of IGAs on improving speaking skills was conducted by the researcher (Putri, 2014) whose study aims at improving the speaking skill of the 8thgrade students. The results from the study showed that the use of IGAs enabled the students to improve their speaking skills. Students were more confident to speak in English. They could retell the story fluently and their vocabulary also increased.

\section{FINDINGS}

Overall, our result indicated that teacher were very positive about the benefits of using IAGs to teach speaking in the English classroom.

\section{A. The Perceptions of EFL Teachers of IGAs in Teaching Speaking}

The internal consistency and reliability of responses to survey questions were assessed in two ways, first by running Scale Test and computing values for Cronbach's Alpha, which is a measure of the international consistency of responses to the questionnaire. 
Table 1: The reliability of questionnaire of teachers' perceptions of IGA in teaching speaking English.

\begin{tabular}{|l|l|l|}
\hline & $\begin{array}{l}\text { Number } \\
\text { of items }\end{array}$ & $\begin{array}{l}\text { Cronbach's } \\
\text { Alpha }(\alpha)\end{array}$ \\
\hline Teachers' perceptions of features of IGA & 5 & .73 \\
\hline $\begin{array}{l}\text { Teachers' perceptions of the usefulness of } \\
\text { IGA in foreign language learning in general }\end{array}$ & 5 & .81 \\
\hline $\begin{array}{l}\text { Teachers' perceptions of role of IGA in } \\
\text { teaching speaking to EFL learners }\end{array}$ & 8 & .89 \\
\hline $\begin{array}{l}\text { Teachers' perceptions of how IGAs should be } \\
\text { used in speaking classes. }\end{array}$ & 7 & .84 \\
\hline
\end{tabular}

As can be seen in Table 1, the value of Cronbach's Alpha $(\alpha)$ was greater than 0.70 for all block of questions, indication that the data are reliable and internally consistent. Secondly, One-Sample T Test was computed to check for significant differences between the mean scores. The results from these $\mathrm{T}$ tests, shown in Table 2 indicated the differences in mean scores were significant different for teachers' perceptions of characteristics of IGAs $(t=5.54, p=0.00)$, the usefulness of IGAs $(t=5.30, p=0.00)$, the role of IGAs $(t=6.61, p=0.00)$, how IGAs should be used in the speaking classroom $(t=6.84, p=0.00)$ and the test value of 3.5 for acceptable level of Oxford's framework is the same. The result of Cronbach's Alpha and the One Sample-T Tests indicate that the survey questionnaire was appropriate for addressing our two research question

Table.2: The value of the questionnaire of teachers' perceptions of IGAs in teaching speaking

\begin{tabular}{|c|c|c|c|c|c|c|}
\hline & \multicolumn{6}{|c|}{ Test Value $=3.5$} \\
\hline & \multirow[b]{2}{*}{$\mathbf{t}$} & \multirow[b]{2}{*}{ df } & \multirow{2}{*}{$\begin{array}{l}\text { Sig. }(2- \\
\text { tailed })\end{array}$} & \multirow{2}{*}{$\begin{array}{c}\text { Mean } \\
\text { Difference }\end{array}$} & \multicolumn{2}{|c|}{$\begin{array}{l}\text { 95\% Confidence } \\
\text { Interval of the } \\
\text { Difference }\end{array}$} \\
\hline & & & & & Lower & Upper \\
\hline Features of IGA & 5.541 & 42 & .000 & .61628 & .3918 & .8407 \\
\hline $\begin{array}{l}\text { Usefulness of IGA in foreign } \\
\text { language learning in general }\end{array}$ & 5.307 & 42 & .000 & .60698 & .3761 & .8378 \\
\hline $\begin{array}{l}\text { Role of IGA in teaching speaking to } \\
\text { EFL learners }\end{array}$ & 6.611 & 42 & .000 & .68605 & .4766 & .8955 \\
\hline $\begin{array}{l}\text { How IGAs should be used in speaking } \\
\text { classes. }\end{array}$ & 6.84 & 42 & .000 & .64950 & .4579 & .8411 \\
\hline
\end{tabular}

(Table 2: Descriptive Statistics)

\section{B. Teachers' perceptions of role of IGAs in teaching speaking}

EFL teachers' perception of the role of IGAs in teaching speaking was analyzed by Descriptive Statistic Test to examine minimum score, maximum score, mean score and standard deviation of this section. 


\section{DOI: $\underline{10.51386 / 25815946 / i j s m s-v 4 i 4 p 132}$}

Volume: 4 Issue: 4

Table 3: Teachers' perceptions of the role of IGAs in teaching speaking

\begin{tabular}{|l|l|l|l|l|l|}
\hline & N & Min & Max & Mean & $\begin{array}{l}\text { Std. } \\
\text { Deviation }\end{array}$ \\
\hline $\begin{array}{l}\text { Teachers' perception of the role } \\
\text { IGAs in teaching speaking }\end{array}$ & 43 & 1.25 & 5.00 & 4.1860 & .68050 \\
\hline
\end{tabular}

The descriptive statistics in Table 3, showed that most teachers strongly agreed that IGAs have an important role to play in teaching students to speak English $(M=4.19, S D=.68)$. This means that most of EFL teachers agreed that IGAs naturally require learners to speak to one another in order to complete the tasks, often engage learners in different modes of interactions, also teach learners to adjust/modify their responses and their questions in order to get the missing piece(s) to complete the tasks, help learners have the chance to have full freedom in working with each other without direct intervention or inference of a third party, and help learners to help each other, support one another not just get what they want but also understand each other and to get understood

In the one-on-one interviews, teachers also agreed with the value of IGAs for teaching students to speak English. Some examples of verbal responses to different statement are given below. In response to the statements. "IGAs requires students to ask and answer questions and encourage them to be more thoughtful"

"It is an activity containing information that learners need to communicate to achieve". (Participant A)

In response to statement, "IGAs give students the chance to have full freedom of working with each other without direct intervention or interference of a third party and the participants also agreed that when using IGAs in teaching speaking":

"Students use words and structures that they see them suitable to present their ideas or information to friends or group". (Participant $C$ )

And in response to the statement, "IGAs give opportunities for learners to learn to help each other, and support one another not just to get what they want but also to understand others and to get understood"

"Students have more interaction because when one student speaks, other students will listen, understand what their friends say and how they say it, and learn from their friends." (Participant A)

\section{Teachers' perception of the usefulness of IGAs in learning language}

In order to examine minimum score, maximum score, mean score and standard deviation of EFL teachers' perception of the usefulness of IGAs in learning language, Descriptive Test was conducted. 


\section{DOI: $\underline{10.51386 / 25815946 / i j s m s-v 4 i 4 p 132}$}

Volume: 4 Issue: 4

Table 4: Teachers' perception of the usefulness of IGAs in learning language

\begin{tabular}{|l|l|l|l|l|l|}
\hline & N & Min & Max & Mean & $\begin{array}{l}\text { Std. } \\
\text { Deviation }\end{array}$ \\
\hline $\begin{array}{l}\text { Teachers' } \\
\text { perception } \\
\text { of the } \\
\text { usefulness } \\
\text { of IGA in } \\
\text { learning } \\
\text { language. }\end{array}$ & 43 & 1.00 & 5.00 & 4.1070 & .75005 \\
\hline
\end{tabular}

Then, the interview data support the result from the questionnaire. All the interviewed participants talked positively about the usefulness of using information gap activities in learning foreign language. They explained:

"The classroom atmosphere is lively and pleasant. Students are more receptive." (Participant C)

"It is useful because students think more and students like to be more active." (Participant D)

In the same vein, the participants also mentioned usefulness that makes IGAs better than other methods in teaching speaking as follows:

"Although students must talk about the topic and main information that the teacher asked, they still use their own words and ideas to express the information they need to answer, and present it to their groups or pairs. The students find it easy to communicate with their friends to complete the content requested by the teacher in the speaking class." (Participant C)

Besides, they all confirmed that information gap activities give more opportunities for each student to speak English. For example:

"Each student has the opportunity to speak more, (Participant A)

"This activity facilitates the whole class to speak because each member is responsible for providing information to the person who is missing it to complete the assigned request." (Participant $C$ )

Simultaneously, the participants also posed some challenges when using IGAs in teaching speaking such as below:

"Some students who do not pronounce well will be afraid of talking." (Participant B)

"Students are afraid of speaking English in front of the class. The class is noisy when the students talk together and some children do not cooperate with their friends. (Participant D)

\subsubsection{Teachers' perceptions of the features of IGAs}

Then mean value for the clusters of teachers' perceptions of the features of IGAs in Table 5suggests that the participants had a tendency to agree with the statements of the questionnaire (with $\mathrm{M}=4.11, \mathrm{SD}=.72$ ). This means that most of them find out that IGAs require learners to often talk to each other to find the missing information so as to complete a task, create a real purpose for learners to communicate with each other to fill a certain information gap, be able to allow learners to work either in pairs or groups and not all activities that create some gap to fill (e.g. gap filling) are IGAs. 


\section{DOI: $\underline{10.51386 / 25815946 / i j s m s-v 4 i 4 p 132}$}

Volume: 4 Issue: 4

Table 5: Teachers perception of the features of IGAs

\begin{tabular}{|l|l|l|l|l|l|}
\hline & N & Min & Max & Mean & $\begin{array}{l}\text { Std. } \\
\text { Deviation }\end{array}$ \\
\hline $\begin{array}{l}\text { Teachers perception of the } \\
\text { features of IGAs }\end{array}$ & 43 & 1.4 & 5.00 & 4.1163 & .72930 \\
\hline
\end{tabular}

After, comments made during the one-on-one interviews confirmed the findings from the questions on statements relating to the teachers' perceptions of the features of IGAs. All of the four participants stated that

"[IGA] is an activity that fills in missing information. [IGA] creates true communication purpose when the communicator needs missing information and the other person also needs to answer according to the content that needs to be answered. If the questioner is not clear, he will also have to ask some more questions to clarify the information he is looking for. (Participant D)

"[IGAs] is the activity that fills in the missing information. It is an activity containing information that learners need to communicate to achieve. It gives each individual the opportunity to speak more in class." (Participant A)

With the same opinions, participant A and B also agreed that information gap activity is the activity to fill missing information. Participant B also clarified the relationship of information and the contents of textbooks.

"[IGA] helps each student have chance to talk". (Participant B)

\section{E. Teachers' perceptions of how of IGAs should be used in speaking classroom.}

The researcher ran a Descriptive Statistics Test to find out scores of minimum, maximum, mean and standard deviation. Most questionnaire respondents agreed with statements on how information gap activities should be used in the classroom $(M=4.14, S D=0.62)$ inTable.6. In other words, teachers perceived that IGAs are useful when the tasks are relevant to learners' knowledge, experience and interests, when the context and content are familiar to them and when the language skills required of the students match their general level of proficiency. Respondents also agreed that the outcome of the tasks need to be described clearly to the learners, and the teacher monitors the class well and to ensure that learners primarily use English in speaking.

Table.6: Teachers' perception of how of IGAs should be used in speaking classroom..

\begin{tabular}{|l|l|l|l|l|l|}
\hline & N & Min & Max & Mean & $\begin{array}{l}\text { Std. } \\
\text { Deviation }\end{array}$ \\
\hline $\begin{array}{l}\text { Teachers' perception of the role } \\
\text { IGAs in teaching speaking }\end{array}$ & 43 & 1.25 & 5.00 & 4.1860 & .68050 \\
\hline
\end{tabular}

(Table 6. Descriptive statistic)

Then Frequency Test was conducted to find out these aspects of each item of the teacher's perception of how IGAs should be used in speaking classroom, illustrated in 7 items. It can be seen from the result in Table. 7 that the items gained the high level of agreements from the participants with more than $80 \%$ statements that IGAs are useful when tasks are relevant to learners' knowledge and experience, the tasks are of learners' interest, the outcome of the tasks is described clearly to the learners and the teacher monitors class well and make sure learners primarily use English in speaking. Over $70 \%$ of the participants agreed that IGAs are useful when tasks adapt to students' proficiency and are not too much above and when learners can use the language knowledge and skills they have learnt to complete the tasks. 
Table7. The level of teachers' perception of IGAs should be used in speaking classroom.

\begin{tabular}{|l|l|l|l|l|l|}
\hline Suggestions & SD & $\mathrm{D}$ & $\mathrm{N}$ & $\mathrm{A}$ & $\mathrm{SA}$ \\
\hline $\begin{array}{l}\text { I believe that IGAs are useful when the tasks are } \\
\text { relevant to learners' knowledge and experience. }\end{array}$ & 24.70 & 13.502 & .712 & .801 & 24.70 \\
\hline $\begin{array}{l}\text { I believe that IGAs are useful when the task are of } \\
\text { learners' interest (e.g. interesting topic). }\end{array}$ & 24.74 & 14.338 & .511 & .835 & 24.74 \\
\hline $\begin{array}{l}\text { I believe that IGAs are useful when what we ask } \\
\text { learners to complete is similar to them. }\end{array}$ & 25.21 & 13.312 & .622 & .817 & 25.21 \\
\hline $\begin{array}{l}\text { I believe that IGAs are useful when the language skills } \\
\text { required of learners to complete the tasks are mainly at } \\
\text { the current level of proficiency and not too much above. }\end{array}$ & 24.88 & 14.677 & .586 & .822 & 24.88 \\
\hline $\begin{array}{l}\text { I believe that IGAs are useful when the outcome of the } \\
\text { tasks is described clearly to the learners. }\end{array}$ & 24.79 & 15.360 & .515 & .832 & 24.79 \\
\hline $\begin{array}{l}\text { I believe that IGAs are useful when the teacher } \\
\text { monitors class well and make sure learners primarily } \\
\text { use English in speaking (not the mother tongue). }\end{array}$ & 24.93 & 14.828 & .611 & .819 & 24.93 \\
\hline $\begin{array}{l}\text { I believe that IGAs are useful when learners can use the } \\
\text { language knowledge and skills they have learnt to } \\
\text { complete the tasks (apart from knowledge of life and } \\
\text { experience). }\end{array}$ & 25.02 & 14.261 & .645 & .813 & 25.02 \\
\hline
\end{tabular}

* Notes: $\mathrm{SD}=$ Stronlyg disagree, $\mathrm{D}=$ Disagree, $\mathrm{N}=$ Neutral, $\mathrm{A}=$ agree, $\mathrm{SA}=$ Stronlyg agree

The one-on-one interviews essentially confirmed the outcome from questionnaire. All interviews agreed with the need to make the outcome of IGAs clear to students:

"I always introduce the topic clearly to help students imagine what they will learn". (Participant D)

In addition, they all had the same opinion of how to use IGAs in teaching speaking:

"I have to move around the class to observe and suggest for students when required, or direct them to the content of the lesson, especially weak students to encourage them". (Participants: A, B, C and D)

Participant $\mathrm{D}$ and $\mathrm{C}$ stated that tasks must be similar to students and at current level of proficiency: class".

"I give simple questions to create vocabulary or provide word suggestions depending on the ability of each group".

"Students use only words and structures that they see fit to present their own ideas to friends or to the

Two interviewees expressed the need to ensure that the information in the tasks is relevant to students' knowledge and experiences:

"Information is in daily life so that students can communicate well". (Participant D)

"The information that is close to life, occurs in daily activities into the content of the lesson". (Participant B)

\section{F. Teachers' reflection on the use of IGAs in speaking classes.}

After measuring reliability of information in this cluster from the Scale test, the result has shown that the contents of this cluster were reliable to conduct the study from the Cronbach'slpha at $8.18(\alpha>.70)$. Besides, the value mean score of the result after running the descriptive test $(M=4.28, S D=0.50)$ has demonstrated that most teachers tended to agree of these items of the practice when using IGAs in speaking classrooms. 


\section{DOI: $\underline{10.51386 / 25815946 / i j s m s-v 4 i 4 p 132}$}

Volume: 4 Issue: 4

July to August 2021

https://www.ijsmsjournal.org

Table. 8: Teacher reflection on the use of IGAs in speaking classes.

\begin{tabular}{|l|l|l|l|l|l|}
\hline & $\mathrm{N}$ & Min & Max & Mean & $\begin{array}{l}\text { Std. } \\
\text { Deviation }\end{array}$ \\
\hline $\begin{array}{l}\text { Teachers' reflection on the use } \\
\text { of IGAs in speaking class. }\end{array}$ & 43 & 3.30 & 5.00 & 4.2814 & .50627 \\
\hline
\end{tabular}

Then, a Frequency test was run to identify participants' aspect of use of IGAs in speaking classes. The result illustrated in Table 9 below shown that most of EFL teachers have sufficient knowledge of using IGAs in speaking classroom.

Table 9: The level of Teachers' reflection on the use of IGAs in speaking classes

\begin{tabular}{|l|l|l|l|l|l|}
\hline Suggestions & $\mathrm{N}$ & $\mathrm{S}$ & $\mathrm{O}$ & $\mathrm{U}$ & $\mathrm{A}$ \\
\hline $\begin{array}{l}\text { I choose IGAs from different sources others more } \\
\text { than textbooks }\end{array}$ & 3 & 5 & 4.49 & .551 & 3 \\
\hline $\begin{array}{l}\text { When I use IGAs, I introduce the topic and make } \\
\text { clear the instruction. }\end{array}$ & 1 & 5 & 4.33 & .865 & 1 \\
\hline $\begin{array}{l}\text { When I use IGAs, I give students opportunities to } \\
\text { practice in groups or pairs. }\end{array}$ & 2 & 5 & 4.19 & .852 & 2 \\
\hline $\begin{array}{l}\text { When I use IGAs, I use authentic teaching } \\
\text { materials like pictures, posters, video clips ... }\end{array}$ & 1 & 5 & 4.14 & 1.146 & 1 \\
\hline $\begin{array}{l}\text { When I use IGAs, I do not interrupt students for } \\
\text { error correction immediately. }\end{array}$ & 43 & 2 & 5 & 4.26 & 43 \\
\hline $\begin{array}{l}\text { When I use IGAs, I give student time to express } \\
\text { their opinions, suggestion and ideas. }\end{array}$ & 43 & 1 & 5 & 4.02 & 43 \\
\hline $\begin{array}{l}\text { When I use IGAs, I group students mixed abilities } \\
\text { to practise. }\end{array}$ & 43 & 3 & 5 & 4.28 & 43 \\
\hline $\begin{array}{l}\text { When I use IGAs, I pre-teach necessary } \\
\text { vocabulary and/ or structure before asking learners } \\
\text { to complete the tasks. }\end{array}$ & 43 & 2 & 5 & 3.91 & 43 \\
\hline $\begin{array}{l}\text { When I use IGAs, I provide students with } \\
\text { opportunities to express their own opinion to } \\
\text { stimulate the students' interest. }\end{array}$ & 43 & 4 & 5 & 4.56 & 43 \\
\hline
\end{tabular}

*(Table 9. Descriptive Statistics - Note: $N=$ never, $S=$ sometimes, $O=$ often, $U=$ usually, $A=$ always

From the data in Table 4.9, the level of the percent has shown that only three items of this cluster involved received responses from participants who agreed that they never had such practices. Respondents revealed that did not choose IGAs from different sources other than textbooks, they provided students with opportunities to express their own opinion to stimulate the students' interest and they went around to be sure that students speak English. Besides, there are a few participants who never practise some activities in speaking classroom such as $2.3 \%$ never introducing the topic and making the instruction clear in, 4,7\% never use authentic teaching materials like pictures, posters, video clips... and 2,3\% never give student time to express their opinions, suggestion and ideas when they use information gap activities in their classroom, most of the participants have a strong agreement with these activities in speaking classes.

When it comes to interview data, all of interviewed participants have the same ideas of how to teach speaking when applying information gap activities

"Create groups by mixing students with different levels into a group because weak and average students can learn from good students, and get help from the teachers". (Participants: A,B,C and D) 


\section{DOI: $\underline{10.51386 / 25815946 / i j s m s-v 4 i 4 p 132}$}

"I need to prepare a topic related to the content of the lesson in the book, sentence patterns that students can use but they forget or do not recognize. I also use pictures. (Participants: A,B,C and D)

All the interviewees reported that they need to prepare the lesson carefully before they use IGAs in teaching speaking because this step is necessary for teaching. A participant said:

"To teach speaking, any activity teachers need to prepare in advance, but the information gap activity gives the speaker more freedom in expression, but the teacher also needs to have a clear orientation for the students to guide them towards the overall goal of the lesson that the teacher wants the students to achieve." (Participant A)

"I need to prepare the information, pictures and steps required for them to do". (Participant D)

"I need to prepare a topic related to the content of the lesson in the book, sentence patterns that students can use but they forget or do not recognize. I also use pictures". (Participant $C$ )

"I prepare questions, pictures and information in life" (Participant B)

In summary, teachers strongly agreed with these statement relating to their perception of IGAs in teaching .From the interview, it was also clear that all participants had a good understanding information gap activities in teaching speaking, by being able to distinguishing the characteristics of IGA from other speaking activities, by understanding the role of information gap activities in learning foreign language, by recognizing the usefulness of IGA in teaching speaking, and by grasping how of information gap activities should be used in speaking classroom

From their responses to statement related to hoe they use IGAs in the classroom, it is clear that teachers had a good understanding of how to use information gap activities in teaching speaking through their efforts to integrate these activities with the contents of the textbook. The data shown that most of them clearly understood what information they needed to bring to speaking classroom and how they could use to teach speaking when using IGA.

\section{DISCUSSION}

\section{Research question 1: What are EFL teachers' perceptions of information gap activity in teaching speaking?}

The study sought to find out the secondary school teachers' perception of IGAs and reflection of using these activities in their speaking classroom. The results shown a number of factors that were considered major concerned by forty- three participants. These five clusters were identified in quantitative data, including teachers' agreement with information about the role of information gap activities in learning foreign language, teachers' understanding of the usefulness of information gap activities in learning foreign language, teachers' high perceptions of the characteristics of IGAs, teachers' knowledge of how information gap activities should be used in speaking classroom and teachers' high suggestion of these activities in teaching speaking. In addition, qualitative data was conducted with four participants to support the quantitative findings by verifying these factors as deeper concerns for the teachers. Setting of data indicated that teachers' perception of IGA in teaching speaking was positive influenced by these factors from the participants' reflection.

\section{Research question 2: What are EFL teachers' reflections on the use of information gap activities in their speaking classes?}

With relating to previous studies, they revealed that information gap activities were viewed as a tool that assists students to improve their speaking competence (Nhan, 2020), to help students be confident when they use their words to talk (YupikaPutri, 2014), to motivate students to talk in freedom atmosphere (Bajaramia, 2016). Participants also shown that preparing information was very important when they used IGA in teaching language, which was related to the factors that affected to the selection of information gap activities in teaching speaking (Hoai, 2012). The opinions and understandings of participants also shown that they had the same perception of the previous studies of IGA in teaching speaking due to the collected data from questionnaire and interview. In addition, the data also indicated that after revealing the usefulness and the role of information gap activities in teaching 


\section{DOI: $\underline{10.51386 / 25815946 / i j s m s-v 4 i 4 p 132}$}

Volume: 4 Issue: 4

speaking, the participants also referred to the challenging like passive students, a noisy classroom, suitable information and vocabulary which always remains in a speaking classroom.

\section{CONCLUSION}

Returning to the questions referred at the beginning of this study, it is now possible to claim that teachers' perceptions of information gap activities in teaching speaking have positive effects on these activities they use in speaking classroom. The results and findings from this paper suggest the teachers who have tendency of agreement of using IGAs, have deeply understood of the use of these activities in their speaking classes. In general, teacher's perceptions of information gap activities are the same positively that is to help learners communicate in real context, to be more active to talk in English language, to get more opportunity to cooperate with others, and to use their own words to present their opinions. However, teachers also have to cope with certain challenges, namely passive students, shy students, poor pronunciation and noisy classroom.

One of the more significant findings to emerge from this study is that teachers' perceptions of information gap activities in teaching were highly positive. It can be concluded that teachers who gained a higher extent in their perception of how of using these activities in speaking classroom. Teachers have shown positive perceptions of their features, usefulness, roles and controlling of information gap activities in the speaking classes which may be due to by the fact that teachers may have insufficient understanding

Overall, this study has significantly broadened our understanding of EFL secondary school teachers' perceptions of information gap activities and the use of these activities in speaking classroom, particularly in relation to the way they use IGAs in classroom. It is suggested that EFL teachers in the Mekong Delta should adopt appropriate for using information gap activities and positive attitudes to teach speaking in order to enhance learners' academic performance. Furthermore, teachers should also consider using different activities to support students in their learning process.

\section{ABOUT THE AUTHORS}

Nguyen Thị Mai Duyen is currently in MA students at Can Tho University. She is an English teacher at a public shool in Vietnam. Her study involves teaching speaking and activities in teaching speaking.

\section{REFERENCES}

[1] Holubec, M. (2012). Univerzita Pardubice.

[2] Defrioka, A. (2017). The Use of Information Gap Activities in Teaching Speaking (Classroom Action Research at SMK). Lingua Didaktika: Jurnal Bahasa Dan Pembelajaran Bahasa, 10(2), 116.

[3] Rafsanjani, A. A., Suwandi, S., Anggani, D., \& Bharati, L. (2020). The Effectiveness of Role-Play and Information-Gap in E-Teaching Speaking Skill for High-Low Self-Confident Students. 10(17), 493-503.

[4] Phan, L. L. H. N. (2017). Challenges / Constraints in Teaching Today' S English in Vietnam: Teachers 'Voices. TESOL Conference 2017, 1-11.

[5] Natsir, R. Y. (2016). Improving Students' Speaking Ability By Using Synchronous Communication Strategy. Exposure : Jurnal Pendidikan Bahasa Dan Sastra Inggris, 5(2), 130

[6] International-Journal-of-Research-in-English-Education-2538-3027. (n.d.). 
[7] Abugohar, M. A., Al-Hnifat, M. A., Al-Smadi, O. A., Rashid, R. A., \& Yunus, K. (2019). English Language Speaking Skill Issues in an EMP Context: Causes and Solutions. International Journal of English Linguistics, 9(3), 211.

[8] Bailey, K. M. (2003). Speaking. In Practical English language teaching.

[9] Arung, F. (2015). Information-Gap Spoken Activities. Research Gate, 4-5.

[10] Almziad, A. (2020). The Reviewing of Benefits of Information Gap Activities in Teaching Second Language Situation. 4(4), 39-44.

[11] Li, X. (2015). The Application of the Information-gap Principle in Promoting English Language Skills in College English Teaching. Iset, $172-174$.

[12] Ismaili, M., \& Bajrami, L. (2016). Information Gap Activities to Enhance Speaking Skills of Elementary Level Students. Procedia - Social and Behavioral Sciences, 232, 612-616. https://doi.org/10.1016/j.sbspro.2016.10.084

[13] Putri, A. Y. (2014). Using information gap activities to improve the speaking skills of grade VIII students at SMP N 7 Yogyakarta. 1-74.

[14] Tsou, W. (2005). Improving speaking skills through instruction in oral classroom participation. Foreign Language Annals, 38(1), 46-55. https://doi.org/10.1111/j.1944-9720.2005.tb02452.x 